\title{
ANALISIS PROSES PEMBELAJARAN PENDIDIKAN AGAMA ISLAM DAN BUDI PEKERTI DENGAN MENGGUNAKAN KURIKULUM 2013 DI SMA NEGERI 1 LINTAU BUO KABUPATEN TANAH DATAR
}

\author{
Syafizizal \\ email: zalsyafri920@gmail.com \\ Mahasiswa Program Pascasa jana Institut Agama Islam Negeri Batusangkar.
}

$+20$

\begin{abstract}
The purpose of this study was to describe the learning process, and obstacles encountered the learning of Islamic Education and Character by using Curriculum 2013 in State High School 1 Lintau Buo. The type of the research is descriptive by using Mix Method. The informants in this research were teachers of Islamic Education and Character, students and headmaster. The data collection techniquee were used in this study interview, observation and documentation. The results obtained indicate that the learning process of Islamic Education and Character has been implemented. However, there were some components of the learning process that has not been done as it should be such using the scientific approach, the use of the media, the use of teaching materials and handling students' character. The efforts were done by school in implementing the curriculum 2013 were providing and expanding school's facilities, conduct training, supervision and evaluation of teachers and students.
\end{abstract}

Keywords: Islamic Education and Character, Learning Process, Curriculum 2013, State High School 1 Lintau Buo

\section{PENDAHULUAN}

Pendidikan merupakan kebutuhan yang sangat esensial dan menjadi kebutuhan primer dewasa ini, di mana ilmu pengetahuan dan teknologi mampu menunjang serta memperlancar seluruh sendi kehidupan dan menduduki peranan penting dalam upaya meningkatkan kualitas sumber daya manusia, baik dalam segi intelektual, sosial, spiritual dan potensial. Peningkatan sumber daya manusia ini bertujuan agar manusia tersebut mampu mengikuti perkembangan ilmu pengetahuan dan teknologi yang akan dihadapinya di masa yang akan datang. Undang-Undang No. 20 Tahun 2003 tentang Sistem Pendidikan Nasional menyatakan bahwa pendidikan adalah usaha sadar dan terencana untuk mewujudkan suasana belajar dan proses pembelajaran agar peserta didik secara aktif mengembangkan potensi dirinya untuk memiliki kekuatan spiritual keagamaan, pengendalian diri, kepribadian, kecerdasan, akhlak ulia, serta 
keterampilan yang diperlukan dirinya, masyarakat, bangsa dan negara (Redaksi Sinar Grafika, 2003).

Banyak upaya yang dilakukan pemerintah dalam peningkatan kualitas pendidikan di antaranya melalui kurikulum 2013. Kurikulum sebagai suatu sistem terdiri dari beberapa komponen-komponen atau bagian-bagian yang saling berkaitan, mendukung dan saling berpengaruh antara yang satu dengan yang lain, serta membentuk satu kesatuan yang tidak bisa terpisahkan (Nurgiyantoro, 2013).

Implementasi kurikulum 2013 merupakan aktualisasi kurikulum dalam pembelajaran dan pembentukan kompetensi serta karakter peserta didik. Hal tersebut menuntut keaktifan guru secara profesional dalam merancang pembelajaran efektif dan bermakna (menyenangkan), mengorganisasikan pembelajaran, memilih pendekatan pembelajaran yang tepat, menentukan prosedur pembelajaran dan pembentukan kompetensi secara efektif, serta menetapkan kriteria keberhasilan (Mulyasa, 2013). Kurikulum 2013 dikembangkan untuk meningkatkan capaian pendidikan dengan 2 (dua) strategi utama yaitu peningkatan efektifitas pembelajaran pada satuan pendidikan dan penambahan waktu pembelajaran di sekolah (Poerwati dan Amri, 2013).
Pada dasarnya mata pelajaran pendidikan Agama Islam dan budi pekerti adalah sama dengan mata pelajaran Agama Islam pada umumnya. Hanya penyebutannya saja yang berbeda karena adanya budi pekerti, perbedaan nama tersebut mengikuti pergantian kurikulum KTSP menjadi Kurikulum 2013. Kandungan dan isi materinya pun sama dengan materi yang ada dalam mata pelajaran Pendidikan Agama Islam (Suharto, 2011). Perbedaannya hanya terletak pada karakteristik dalam proses pembelajarannya, karena pada kurikulum 2013 isi dari mata pelajaran pendidikan Agama Islam dan budi pekerti harus mencakup 18 karakter, dan lebih mengutamakan peserta didik yang berperan aktif dalam proses pembelajaran. Pendidikan Agama Islam dan Budi Pekerti adalah suatu bimbingan dan asuhan terhadap anak didik agar nanti setelah selesai dari pendidikan dapat memahami, menghayati dan mengamalkan apa yang terkandung dalam Islam secara keseluruhan (Daradjat, 1996)

Sekolah merupakan suatu lembaga formal yang mempersiapkan peserta didik dan sumber daya manusia yang berkualitas. Dalam hal ini mata pelajaran pendidikan agama dan budi pekerti yang sangat berperan penting dalam mengembangkan akhlak, sikap atau moral para peserta didik. Bukan hanya peserta didik yang pandai dalam hal kognitif, tapi juga pandai dalam hal afektif. Dengan demikian 
akan terjadinya keseimbangan antara dua kecerdasan tersebut, dan menghasilkan peserta didik yang secara intelektual berkualitas serta secara akhlak dan perilaku sehari-hari yang berkuantitas sesuai ajaran Islam (Suharto, 2011).

SMA Negeri 1 Lintau Buo termasuk tiga dari sekolah yang sudah melaksanaan kurikulum 2013 pada tahun 2014 di Kabupaten Tanah Datar. Di sekolah tersebut semua mata pelajaran sudah melaksanakan kurikulum 2013. SMA Negeri 1 Lintau Buo salah satu SMA favorit dan terbaik di Tanah Datar ini dibuktikan dengan banyaknya siswa/siswi mendaftar masuk sekolah ini, di samping itu letaknya yang strategis membuat orang tua siswa/siswi tidak khawatir dengan transportasi anaknya ke sekolah karena banyak transportasi yang lewat di depan sekolah karena sekolah ini berada di Jl. Raya Balai Tengah, Payakumbuh. Selain terbaik, SMA Negeri 1 Lintau Buo juga banyak mendapatkan prestasi, baik di tingkat daerah maupun provinsi, salah satunya predikat terbaik pelaksanaan kegiatan pramuka, dan maju ke tingkat provinsi mewakili Tanah Datar untuk sekolah sehat dan lain sebagainya (Studi Dokumentasi pada Blog Dinas Pendidikan Tanah Datar, 2015).

Dari gambaran SMA Negeri 1 Lintau Buo tersebut di sini peneliti ingin melihat bagaimana pelaksanaan pembelajaran Pendidikan Agama Islam dan Budi Pekerti menggunakan kurikulum 2013. Maka dari itu peneliti melakukan observasi dan wawancara kepada kepala sekolah, guru Pendidikan Agama Islam dan Budi Pekerti yaitu ibu Kasmiati dan Ismar Ismail. Dari hasil observasi dan wawancara tersebut masih ada terdapat permasalahan dalam pelaksanaan pembelajaran menggunakan kurikulum 2013 (Hasil Wawancara dan Observasi 13 Oktober 2015). Di samping itu sejak SMA Negeri 1 Lintau Buo melaksanakan kurikulum 2013, belum ada yang melakukan analisis tentang proses pembelajaran pada mata pelajaran Pendidikan Agama Islam dan Budi Pekerti yang dijadikan karya tulis ilmiah.

Ada beberapa penelitian terdahulu yang menjadi tolak ukur bagi penelitian ini yaitu Ferry pada tahun 2015 tentang Analisis Proses Pembelajaran Biologi Pada Materi Protista Kelas X SMA Negeri 5 Sungai Penuh. Berdasarkan hasil penelitian yang dilakukan, Ferry menemukan bahwa proses pembelajaran kurang terlaksana dengan baik. Senada dengan Ferry, Admisa pada tahun 2013 menulis tentang Analisis Proses dan Hasil Belajar Fisika Siswa pada Pembelajaran Besaran dan Satuan di Kelas X SMA Negeri 13 Kerinci. Admisa juga menemukan bahwa pelaksanaan proses 
pembelajaran juga terlaksana dengan baik, beberapa tahapan proses pembelajaran tidak sesuai dengan RPP.

Kemudian, Wahyuni pada tahun 2011 menulis tentang Analisis Proses Pembelajaran pada Pokok Bahasan Ikatan Kimia di Kelas X SMAN 112 X 11 Enam Lingkung. Wahyuni menemukan bahwa proses pembelajaran masih kurang terlaksana dengan baik. Selain itu, Sari pada tahun 2012 menulis tentang Analisis Proses Pembelajaran Biologi pada Materi Sistem koordinasi dan Alat Indra pada Manusia kelas IX di SMP Negeri 23 Padang. Sari menemukan bahwa proses pembelajaran yang diamati belum optimal terlaksana. Selanjutnya Herlina pada tahun 2015 menulis tentang Analisis Proses Pembelajaran dan Pemahaman Siswa pada Materi Larutan Penyangga di Kelas XI IPA 1 SMA Negeri 1 Sasak. Herlina juga mendapatkan informasi yang sama dengan peneliti sebelumnya yaitu proses pembelajaran belum terlaksana dengan baik.

Dalam Penelitian ini peneliti melakukan penelitian yang sama dengan penelitian di atas, penelitian yang peneliti lakukan adalah Analisis Proses Pembelajaran Pendidikan Agama Islam dan Budi Pekerti dengan menggunakan Kurikulum 2013 di SMA Negeri 1 Lintau Buo Kabupaten Tahan Datar. Peneliti berupaya mendeskripsikan proses pembelajaran, kendala dan upaya pelaksanaan pembelajaran Pendidikan Agama Islam dan Budi Pekerti dengan menggunakan Kurikulum 2013 di SMAN 1 Lintau Buo Kabupaten Tahan Datar.

\section{METODE PENELITIAN}

Penelitian ini merupakan penelitian kualitatif dan kuantitatif atau mix method (Ainin, 2007). Pendekatan yang digunakan adalah deskriptif analitik yaitu suatu penelitian yang mendeskripsikan data, fakta, dan kecenderungan yang terjadi yang kemudian dianalisis dan direkomendasikan mengenai apa yang harus dibangun untuk mencapai suatu keadaan (Jhonson dan Christensen, 2004). Menurut Sudjana (2001) penelitian deskriptif analitik adalah data yang diperoleh dari penelitian kualitatif seperti hasil pengamatan, hasil wawancara, hasil pemotretan, cuplikan tertulis dari dokumen, catatan lapangan, disusun peneliti di lokasi penelitian tidak dituangkan dalam statistic. Di sini peneliti melakukan analisis dengan memperkaya informasi melalui analisis komparasi, sepanjang tidak menghilangkan data aslinya. Hasil analisis berupa pemaparan gambaran mengenai proses pembelajaran Pendidikan Agama Islam dan Budi Pekerti dengan menggunakan kurikulum 2013 di SMA Negeri 1 Lintau Buo dalam bentuk naratif.

Teknik pengumpulan data yang digunakan adalah wawancara, observasi 
dan dokumentasi. Definisi wawancara menurut Stewart \& Cash seperti yang dikutip oleh Hardiansyah (2011) adalah An interview isinteractional because there is an exchanging, or sharing of roles, responsibilities, feelings, beliefs, motives, and information. If one person does all of the talking and the other all of the listening, a speech to an audience of one, not an interview, is talking place. Bahwa wawancara diartikan sebagai sebuah interaksi yang di dalamnya terdapat pertukaran atau berbagai aturan, tanggung jawab, perasaan, kepercayaan, motif, dan informasi.

Wawancara bukanlah suatu kegiatan dengan kondisi satu orang melakukan/ memulai pembicaraan sementara yang lain hanya mendengarkan. Sedangkan menurut Riduwan (2005) wawancara yaitu suatu cara pengumpulan data yang digunakan untuk memperoleh informasi langsung dari sumbernya. Wawancara yang peneliti lakukan adalah wawancara langsung dengan 2 (dua) orang guru Pendidikan Agama Islam dan Budi Pekerti dan Kepala Sekolah untuk mendapatkan data tentang kendala dalam proses pembelajaran dengan menggunakan kurikulum 2013, dan usaha kepala sekolah dalam mengimplementasikan kurikulum 2013. Data wawancara berupa lembaran wawancara yang ditujukan kepada 2 (dua) orang guru Pendidikan Agama Islam dan
Budi Pekerti dan Kepala Sekolah, SMA Negeri 1 Lintau Buo.

Kemudian peneliti melakukan observasi, menurut Sutrisno (2006) observasi diartikan sebagai pengamatan dan pencatatan dengan sistematis atas fenomena-fenomena yang diteliti. Observasi yang peneliti lakukan adalah dengan mengamati tahapan pelaksanaan dalam proses pembelajaran Pendidikan Agama Islam dan Budi Pekerti pada kurikulum 2013 serta data yang dapat menunjang kelengkapan penelitian ini. Data observasi berupa pedoman observasi yang diisi oleh peneliti dan observer secara langsung di kelas ketika jalannya proses belajar mengajar di kelas X dan IX selama 6 kali pertemuan. Selain itu peneliti juga menggunakan dokumentasi yang ditujukan untuk memperoleh data langsung dari tempat penelitian, meliputi buku-buku yang relevan, peraturan-pertaturan, laporan kegiatan, foto-foto, film, dan data yang relevan dengan penelitian (Riduwan, 2005). Dokumentasi yang peneliti lakukan yaitu foto, rekaman suara dan rekaman video proses pembelajaran Pendidikan Agama Islam dan Budi Pekerti di kelas X dan IX SMA Negeri 1 Lintau Buo.

Dalam pengolahan data, peneliti mengunakan data kuantitatif dan data kualitatif. Data kuantitatif didapatkan dengan menggunakan teknik pengisian 
pedoman observasi. Pedoman observasi merupakan teknik pengumpulan data yang dilakukan dengan cara memberi seperangkat pernyataan tertulis kepada observer untuk diisi sesuai dengan keadaan proses pembelajaran yang diamati di lapangan. Setelah pedoman observasi diisi, selanjutnya pedoman tersebut diolah dengan menjumlahkan hasil observasi dan kemudian dinilai dengan menggunakan kategori penilaian. Sedangkan pengolahan data kualitatif menurut Moleong (2006) adalah dengan langkah-langkah sebagai berikut 1) mengedit data, yaitu menyusun data sesuai dengan tujuan yang diinginkan; 2) membaca, menela'ah dan mencatat sumber data yang telah dikumpulkan; 3) menghimpun sumber data yang berkaitan dengan masalah yang akan diteliti; 4) mengklasifikasikan data sesuai dengan batasan masalah yang diteliti; 5) Interpretasi data, yaitu setelah data dihimpun dan diklasifikasikan, maka peneliti menguraikan dengan kata-kata; dan 6) menarik kesimpulan akhir.

Adapun dalam melakukan analisis data kuantitatif menurut Arikunto (2005) 1) menjumlahkan semua tanda centang yang ada pada setiap kolom; 2) menjumlahkan seluruh uraian (instrument) yang terdapat di dalam kolom; 3) menghitung persentase dalam setiap kolom dengan menggunakan rumus. Adapun dalam melakukan analisis data kualitatif menurut Sugiyono (2007) ada beberapa tahap antara lain 1) reduksi data, mereduksi data berarti merangkum, memilih hal-hal yang pokok, memfokuskan pada hal-hal yang penting, dicari tema dan polanya membuang yang tidak perlu; 2) penyajian data bisa dilakukan dalam bentuk uraian singkat, bagan, hubungan antar kategori yang paling sering digunakan untuk menyajikan data dalam penelitian kualitatif adalah dalam teks yang bersifat naratif. Dengan menyajikan data, maka akan memudahkan untuk memahami apa yang terjadi, merencanakan kerja selanjutnya berdasarkan apa yang dipahami; dan 3) penarikan kesimpulan (Miles dan Huberman, 2007). Kesimpulan awal yang dikemukakan masih bersifat sementara, dan akan berubah bila tidak ditemukan buktibukti yang kuat yang mendukung pada tahap pengumpulan data berikutnya.

\section{HASIL PENELITIAN DAN PEMBAHASAN}

\section{Proses Pembelajaran PAI dengan Menggunakan Kurikulum 2013 di SMA Negeri 1 Lintau Buo}

Berdasarkan hasil observasi pada kegiatan pendahuluan dapat dikatakan bahwa secara umum informan sudah membimbing siswa untuk kegiatan orientasi, apersepsi, motivasi dan pemberian acuan. Secara umum hasil pengamatan kegiatan pendahuluan 
dikategorikan "cukup dan kurang". Hal ini berarti bahwa dalam pelaksanaan tersebut informan belum melaksanakan dengan baik.

Rendahnya kegiatan motivasi dan pemberian acuan ini disebabkan karena informan tidak terbiasa melakukan kegiatan tersebut. Selain itu, informan sering lupa, sehingga setelah melakukan apersepsi, informan lansung saja pada tahap kegiatan inti (Hasil Observasi, 14-27 Januari 2016). Seharusnya yang dilakukan informan pada tahap pendahuluan ini menurut Permendikbud 103 tahun 2014 meliputi kegiatan pendahuluan, di antaranya 1) mengondisikan suasana belajar yang menyenangkan/orientasi; 2) mendiskusikan kompetensi yang sudah dipelajari dan dikembangkan sebelumnya berkaitan dengan kompetensi yang akan dipelajari dan dikembangkan/apersepsi; 3) menyampaikan kompetensi yang akan dicapai dan ada manfaatnya dalam kehidupan seharihari/motivasi; 4) menyampaikan garis besar cakupan materi dan kegiatan yang akan dilakukan/pemberian acuan; dan 5) menyampaikan lingkupan dan teknik penilaian yang akan digunakan.

Pengamatan terhadap kegiatan pendahuluan juga dilakukan kepada siswa, dan didapatkan bahwa motivasi siswa untuk mengikuti proses pembelajaran dan pemahaman tujuan pembelajaran yang dilaksanakan siswa dikategorikan "cukup dan kurang". Hal ini berarti bahwa dalam pelaksanaan tersebut siswa kurang termotivasi dan kurang memahami tujuan pembelajaran dengan baik. Kurangnya motivasi dan rendahnya pemahaman siswa terhadap tujuan pembelajaran disebabkan oleh beberapa faktor di antaranya oleh siswa itu sendiri karena datang terlambat, mempunyai masalah di rumah sebelum berangkat ke sekolah dan kurangnya niat untuk mengikuti pembelajaran. Selain siswa, informan juga merupakan faktor penyebab rendahnya motivasi siswa dan pemahaman tujuan pembelajaran, karena informan tidak terbiasa melakukan kegiatan tersebut (Hasil Observasi, 14-27 Januari 2016).

Pada kegiatan inti, informan sudah membimbing siswa untuk kegiatan mengamati, menanya, mengumpulkan data, mengasosiasi, mengkomunikasikan, menggunakan model pembelajaran, media pembelajaran dan bahan pembelajaran. Namun masih ditemukan dua orang informan yang belum melaksanakan tahapan kegiatan inti dengan baik.

Kurangnya kegiatan mengasosiasi, penggunaan model pembelajaran dan penggunaan media disebabkan karena informan kurang terbiasa melakukan kegiatan mengasosiasi atau menalar sedangkan dalam kegiatan mengasosiasi, 
informan dan peserta didik merupakan pelaku aktif, pemahaman informan dan siswa tentang model tersebut masih kurang, dalam penggunaan media, informan tidak terbiasa menggunakan komputer dan ketersediaan infocus terbatas sehingga informan jarang menggunakan media dalam pembelajaran (Hasil Observasi, 14-27 Januari 2016). Seharusnya yang dilakukan informan pada tahap kegiatan inti menurut Permendikbud 103 tahun 2014 meliputi menggunakan pendekatan saintifik yang disesuaikan dengan karakteristik mata pelajaran dan peserta didik. Informan memfasilitasi peserta didik untuk melakukan proses mengamati, menanya, mengumpulkan informasi/ mencoba, menalar/mengasosiasi, dan mengomunikasikan. Pengamatan terhadap kegiatan inti juga dilakukan kepada siswa. Hasil pengamatan tersebut siswa masih malu-malu dalam hal mempersentasikan dan memyimpulkan hasil diskusi atau temuannya dan belum menggunakan media pembelajaran waktu mempersentasikan materi, sesuai pengamatan peneliti tanggl 14-27 Januari 2016 hal ini dikategorikan "kurang".

Berdasarkan hasil observasi dapat dikatakan bahwa secara umum pada kegiatan penutup, informan sudah membimbing siswa untuk kegiatan menyimpulkan pembelajaran, penilaian, refleksi, dan tindak lanjut. Namun masih ditemukan dua orang informan belum melaksanakan kegiatan penutup dengan baik.

Ada beberapa tahap penutup yang kurang terlaksana dengan baik oleh informan, seperti kegiatan tindak lanjut dikategorikan "sedang" dan kegiatan menyimpulkan pembelajaran dan melakukan refleksi diklasifikasikan "cukup" ini disebabkan informan tidak melihat waktu sehingga lima belas menit waktu akan habis dan informan hanya melakukan tes. Selain itu, informan sering lupa sehingga setelah melakukan kegiatan mengkomunikasikan pada kegitan inti, informan lansung saja pada penilaian/ melakukan tes. Seharusnya yang dilakukan informan pada tahap penutup ini menurut Permendikbud 103 tahun 2014 meliputi 1) membuat rangkuman/ simpulan pelajar; 2) melakuakn refleksi terhadap kegiatan yang sudah dilaksanakan; dan 3) memberikan umpan balik terhadap proses dan hasil pembelajaran. Kegiatan guru yaitu 1) melakukan penilaian; 2) merencanakan kegiatan tindak lanjut dalam bentuk pembelajaran remidi, program pengayaan, layanan konseling dan memberikan tugas baik tugas individu maupun kelompok sesuai dengan hasil belajar peserta didik; dan 3) menyampaikan rencana pembelajaran pada pertemuan berikutnya. Peneliti juga melakukan pengamatan kepada siswa. 
Hasil pengamatan tersebut didapatkan dari pengamatan peneliti pada tanggal 14-27 Januari, didapatkan bahwa kegiatan menyimpulkan, mengikuti tes, melakukan refleksi dan mengerjakan tindak lanjut yang dilaksanakan oleh siswa dikategorikan "kurang dan cukup" dikarenakan siswa terburu-buru ingin keluar dari kelas untuk beristirahat.

\section{Kendala Proses Pembelajaran Pendidikan Agama Islam dan Budi Pekerti dengan Menggunakan Kurikulum 2013 di SMA Negeri 1 Lintau Buo.}

Berdasarkan hasil wawancara tanggal 18 dan 27 Januari 2016 dengan informan I dan informan II, didapatkan bahwa pada tahapan pendahuluan informan I dan informan II tidak memiliki kendala dalam pelaksanaan tahapan pendahuluan. Namun informan I dalam hal mempersiapkan RPP mendapatkan masalah dalam pembuatannya. Sedangkan informan II juga mendapatkan masalah dalam mempersiapkan RPP disebabkan karena informan baru pindah dari MAN, waktu di MAN dulu informan masih menggunakan KTSP, jadi informan kurang mendapatkan pelatihan tentang Kurikulum 2013. Pada tahapan kegiatan inti, guru sudah melaksanakan kegiatan inti dengan baik, namun ada beberapa kendala dalam penggunaan media dan bahan ajar. Selain itu, guru juga memiliki kendala dalam menghadapi siswa yang berbedabeda. Sedangkan pada kegiatan penutup informan I memiliki kendala pada tahap ini, di antaranya pada tahapan penilaian, guru merasa kesulitan karena cara penilaian kurikulum 2013 berbeda dengan KTSP. Sedangkan informan II memiliki kendala pada masalah waktu, sehingga tahapan penutup ada yang tidak efektif dilaksanakan.

\section{Usaha yang dilakukan pihak sekolah dalam Mengimplementasikan Kurikulum 2013 di SMA Negeri 1 Lintau Buo}

Hasil wawancara tanggal 14 Januari 2016 yang didapatkan dari Wakil Kepala Kurikulum SMA Negeri 1 Lintau Buo bahwa usaha yang dilakukan dalam bidang sarana dan prasarana adalah dengan menyediakan atau menambah fasilitas yang dapat menunjang kegiatan pembelajaran dalam menerapkan kurikulum 2013 ini. Pihak sekolah sudah melakukan usaha dalam mengimplementasikan kurikulum 2013. Selain usaha dalam sarana dan prasarana, pihak sekolah juga melakukan usaha dalam kegiatan yang dilakukan untuk guru dan siswa di antaranya MGMP dan pelatihan untuk guru, serta kegiatan ektra dan intra yang dilakukan untuk siswa.

Setelah dilakukan kegiatan, pihak sekolah juga melakukan pengawasan terhadap guru dan siswa di antaranya mengecek kehadiran 
dalam setiap kegiatan yang dilakukan guru dan siswa. Adapun usaha yang dilakukan dalam penilaian terhadap guru dan siswa dalam mengimplementasikan kurikulum 2013 adalah menilai perangkat dan proses pembelajaran guru dan untuk siswa menilai keaktifan dan sikap siswa dalam proses pembelajaran dan kegiatan ektra dan intra sekolah.

Usaha lain yang dilakukan pihak sekolah adalah mengadakan peringatan hari besar agama dan nasional. Hal ini bertujuan agar guru dan siswa memiliki sikap relijius dan patriotisme terhadap Negara. Kendala yang dialami oleh pihak sekolah dalam mengimplementasikan kurikulum 2013 adalah masalah dana yang belum memadai sehingga fasilitas untuk guru dan sekolah masih ada yang kurang. Selain itu, kurangnya potensi guru dalam menggunakan teknologi dan potensi siswa untuk berkreasi dan belajar.

\section{KESIMPULAN}

Dari hasil penelitian yang telah dilakukan di SMA Negeri 1 Lintau Buo tentang analisis proses pembelajaran Pendidikan Agama Islam PAI menggunakan kurikulum 2013 dapat disimpulkan bahwa proses pembelajaran Pendidikan Agama Islam dan Budi Pekerti di SMA Negeri 1 Lintau Buo sudah terlaksana. Namun ada beberapa komponen proses pembelajaran yang belum terlaksana sebagaimana mestinya, seperti pada tahapan pendahuluan, guru kurang melaksanakan kegiatan motivasi, pemberian acuan dan pada kegiatan inti guru kurang melaksanakan kegitan mengasosiasikan, menggunakan model pembelajaran dan menggunakan media pembelajaran, sedangkan pada kegatan penutup guru kurang melakukan kegiatan refleksi dan tindak lanjut dalam pembelajaran. Dari segi kendala, guru masih memiliki kendala terkait dengan pendekatan saintifik, penggunaan media, penggunaan bahan ajar dan penanganaan karakter siswa. Sedangkan usaha yang dilakukan oleh pihak sekolah dalam mengimplementasikan kurikulum 2013 adalah menyediakan dan menambah fasilitas, melakukan kegiatan pelatihan, pengawasan dan penilaian terhadap guru dan siswa.

Berdasarkan kegaitan penelitian tersebut, terdapat beberapa saran yaitu 1) guru diharapkan bisa menerapkan kurikulum 2013 dalam proses pembelajaran dengan cara meningkatkan kemampuan dalam kurikulum 2013, termasuk melibatkan diri dalam kegiatan MGMP dan pelatihan untuk kurikulum 2013; (2) guru seharusnya bisa menggunakan bahan ajar dan media dalam proses pembelajaran dengan baik; dan (3) guru hendaknya bisa mengelola kelas pada siswa yang memiliki perbedaan karakter. 


\section{KEPUSTAKAAN ACUAN}

Admisa, Wilfa. (2013). "Analisis Proses dan Hasil Belajar Fisika Siswa pada Pembelajaran Besaran dan Satuan di Kelas X SMA Negeri 13 Kerinci”. Tesis.

Ainin, Moch. (2007). Metodologi Penelitian Bahasa Arab. Pasuruan: Hilal Pustaka.

Arikunto, Suharsimi. (2005). Manajemen Pendidikan. Jakarta: Rineka Cipta. Endah. Loeloek.

Blog Dinas Pendidikan Tanah Datar 2015.

Daradjat, Zakiah. (1996). Ilmu Pendidikan Islam. Jakarta: Bumi Aksara.

Ferry, Darma. (2015). “Analisis Proses Pembelajaran Biologi Pada Materi Protista Kelas XSMA Negeri 5 Sungai Penuh”. Tesis

Herdiansyah, Haris. (2011). Metodologi Penelitian Kualitatif untuk Ilmu-ilmu Sosial, Jakarta: Salemba Humanika.

Herlina. (2015). "Analisis Proses Pembelajaran dan Pemahaman Siswa pada Materi Larutan Penyangga di Kelas XI IPA 1 SMA Negeri 1 Sasak". Tesis.

Jhonson, Burke \& Christensen, Larry. (2004). Educational Research Quantitave, Qualitative, and Mixed Approach, Boston: Pearson Education.
Milles, Mattew B \& Huberman, A Michael. (2007). Analisis Data Kualitatif. Jakarta: UI Press.

Moleong, Lexy. J. (2006). Metode Penelitian kualitatif. Bandung: Remaja Rosda Karya.

Mulyasa, E. (2013). Pengembangan dan Implementasi Kurikulum 2013. Bandung: PT Remaja Rosdakarya.

Nurgiyantoro, Burhan. (2013). Dasar-Dasar Pengembangan Kurikulum Sekolah. Yogyakarta: BPFE.

Permendikbud Nomor 103 tentang Standar Proses Pembelajaran Tahun 2014.

Poerwati dan Sofan Amri (2013). Panduan Memahami Kurikulum 2013. Jakarta: PT. Prestasi Pustakarya.

Redaksi Sinar Grafika. (2003). UndangUndang SISDIKNAS (Sistem Pendidikan Nasional) 2003, Jakarta: Sinar Grafika.

Riduwan. (2005). Belajar Mudah Penelitian untuk Guru, Karyawan dan Peneliti Pemula. Bandung: Alfabeta.

Sari, Wuri Komala. (2012). "Analisis Proses Pembelajaran Biologi pada Materi Sistem koordinasi dan Alat Indra pada Manusia kelas IX di SMP Negeri 23 Padang". Tesis. 
Sudjana, Nana Ibrahim. (2001). Penelitian Sutrisno, Hadi. (2004). Metodologi Reseach dan Penilaian Pendidikan. Bandung: Jilid 2. Yogyakarta: Andi Publisher. Sinar Baru Algensindo.

Sugiyono. (2007). Metode Penelitian Wahyuni, Sisri. (2011). "Analisis Proses Pendidikan, Bandung. Pembelajaran pada Pokok Bahasan Ikatan Kimia di Kelas X SMAN 112 X

Suharto, Toto. (2011). Filsafat Pendidikan 11 Enam Lingkung”. Tesis. 